Article

\title{
Developing a Corporate Social Responsibility Strategy in India Using the SA 8000 Standard
}

\author{
Federica Murmura * ${ }^{\mathbb{D}}$ and Laura Bravi $\mathbb{D}$ \\ Department of Economics, Society, Politics, University of Urbino Carlo Bo, Via Saffi 42, 61029 Urbino, Italy; \\ laura.bravi@uniurb.it \\ * Correspondence: federica.murmura@uniurb.it; Tel.: +39-072-230-5592
}

Received: 26 March 2020; Accepted: 22 April 2020; Published: 24 April 2020

\begin{abstract}
In today's global markets, issues related to Corporate Social Responsibility have greater importance on business performance, and international standards are defined as tools for companies to internalize their sustainability requests. The aim of this paper is to understand how the Social Accountability 8000 (SA 8000) standard is managed by developing countries, focusing on Indian certified companies, analyzing, in detail, of the motivations and benefits that prompted them to certification and barriers to its implementation. The research is based on a qualitative multiple case study. A total number of six companies participated in the research. The study showed that one of the main reasons for Indian companies of being SA 8000 certified is the willingness to satisfy the request for greater transparency on the part of stakeholders and the market in general. The study shows that by certifying SA 8000, Indian textile companies want to be promoters of a more sustainable and ethical way of doing business. The value of the research lies in the decision to focus on the Indian market, and in the textile sector, since India is the first country with the largest number of SA 8000 certified companies among developing countries and its textile industry is relevant all around the world.
\end{abstract}

Keywords: Corporate Social Responsibility; SA8000; ethical standard

\section{Introduction}

The definition of Corporate Social Responsibility (CSR) seems to embrace a vast number of concepts evolving towards sustainability: it is traditionally framed as environmental concerns, public relations, corporate philanthropy, human resource management and community relations [1].

Over the years, the concept of CSR has evolved within a shareholder-stakeholder debate [2]. In contrast to the shareholder model, the stakeholder theory is based on the notion that beyond shareholders, there are several agents with an interest in the action and decision of companies. Stakeholders are those who benefit from or are harmed by, and whose rights are violated or respected by business actions [3]. In addition to shareholders, they include creditors, employees, customer, suppliers and the communities. The stakeholder theory asserts that companies have a social responsibility that requires them to consider the interest of all parties affected by their action. The responsibility is built into the business strategy of the company and it includes responsibility towards all stakeholders. As a result of globalization and fast-paced business environments, stakeholders and different national legislations put new expectations on business, altering how social, environmental and economic impacts should be optimally balanced in the decision-making process [4]. Researchers in this decade tended to associate CSR with other relevant issues in addition to the stakeholder theory, such as business ethics, corporate citizenship, corporate social performance (CSP) and sustainable development [5]. As for enhancing the importance of sustainable development as part of a CSR strategy, on 25 September 2015,193 countries agreed and adopted a set of goals as part of a new global sustainable development agenda. The Sustainable Development Goals (SDGs) define global priorities for 2030 and represented 
an opportunity to put the world on a sustainable path. There are 17 goals in total, each with a number of targets, totaling 169 targets across the 17 goals. The goals covered the three dimensions of sustainable development: economic growth, social inclusion and environmental protection [6].

Considering that, in this study, CSR is defined as the integration of business operations and values, whereby the interests of all stakeholders including investors, customers, employees and the environment are reflected in the company's policies and actions $[7,8]$.

Despite numerous contributions from around the world, most of the academic literature on CSR has developed in the United States (US); it is there that the main CSR theories emerged for the first time. The main reason lies in the specific characteristics of the US corporate system [9], characterized by not very regulated capitals and labor markets, low levels of state social security and a great value for individual freedom and responsibility. As a result, many social issues such as education, health care, or community investment have traditionally been debated in the context of CSR [10]. In other parts of the world, in particular Europe, the Far East and Australia, however, there has always been a tendency to address social issues through government policies, and therefore, CSR in these areas has always been the subject of institutional codifications and regulations, mandatory for companies. For example, European continental companies have traditionally considered social issues (such as the provision of health care, the fight against climate change, etc.) a government competence. The active engagement of these companies in terms of social responsibilities has mainly spread and developed thanks to their foreign affairs, in countries where the regulatory frameworks were very different from those in Europe. In fact, multinational companies can be considered today the main actors for the diffusion of CSR in Europe and beyond [11]. In particular, the attempt of industrialized countries to impose social conditions similar to their own on socially developing countries, or at least conform to the international standards developed by the International Labor Organization (ILO) and the Organization for the Cooperation and Economic Development (OECD), have led global companies to implement strategies of social responsibility at the global level $[12,13]$.

International standards may be a tool through which companies are able to internalize the sustainability requests. These standards deal with different aspects of the CSR agenda and offer a certification against specific requirements. Well-known examples of such standards are the Global Reporting Initiative (GRI), the Fair Labor Association (FLA), and Accountability 1000 (AA 1000); however, the most known and applied worldwide is the Social Accountability 8000 (SA 8000) [14]. The International SA 8000 standard is considered to be a multi-stakeholder standard, and the member groups include not only businesses, but also certified bodies, non-governmental organizations, academia and trade unions [15-17]. Developed in 1997 by the American non-profit organization for human rights "Social Accountability International" (SAI), SA 8000 deals with issues related to human rights in the workplace including child exploitation, forced labor, discrimination, health and safety of workers, freedom of association, the right to collective bargaining, disciplinary practices, timetables and remuneration [18]. In addition to national laws, its guiding principles are the conventions of the International Labor Organization (ILO) and the United Nations Organization (UN), including the Universal Declaration of Human Rights. Data updated as of 31 December 2018 show the presence of 3996 companies certified in 64 countries worldwide, for a total of 2,047,066 workers involved. Since its introduction in 1998, the growth in the number of certified companies has continued uninterruptedly for nineteen years. In 2017, for the first time, the annual growth rate was negative, with a rate of minus $10 \%$ compared to 2016 [19].

However, there is a gap of empirical research studies on the diffusion of social responsibility standards and the effects of the SA 8000 certification, and existing studies are concentrated in a limited number of countries and industries [20-22]. In fact, according to Arminen et al. [22], since CSR may even differ within an industry due to companies' varying visibility, resources, objectives and motivations, it is important to include company, industry, and country level determinants when studying CSR. Llach et al. [20] stated also that social standards have only been modestly adopted in comparison with other standards such as ISO 9001 or ISO 14001 and the study of their diffusion is 
quite scarce so that more information is needed regarding the diffusion of these standards to better understand the phenomenon and its impacts. The same is stated by Sartor et al. [21], who define the academic literature on SA 8000 as still limited. Furthermore, Zhu and Lai [23] underline whether and how suppliers in developing countries respond to pressures from multinational enterprises, for CSR practices is lacking related studies.

Therefore, following the lines of Santos et al. [24], the aim of this paper is to understand how the International SA 8000 standard is managed by developing countries focusing on Indian certified companies, analyzing, in detail, motivations that prompted companies to the certification, and evaluating their perceived benefits and barriers to the implementation of the standard.

It has been decided to focus on the Indian market, focusing, in detail, on the textile sector, because India, with 977 certified companies, is the second country after Italy (with 1309 certified companies) which has the largest number of SA 8000 certified companies in the world, and the first among developing countries, followed by China (606 certified companies) [19]. Moreover, since more than $80 \%$ of the certified Indian organizations belong to the textile sector, it was decided to focus on this sector, one of the oldest in the country and, after agriculture, the one with the highest number of employees (approx. 45 million people) [25]. The literature review section better explains the motivations that led to the choice of Indian companies as reference sample for this study (see Section 2.1).

The paper is structured as follows: Section 2 reviews the literature on motivations, benefits and barriers of SA 8000 in the context of developed and developing countries, focusing in detail on the Indian context; Section 3 describes the methodology of the research; Section 4 presents the findings and discusses them, and finally, is followed by Conclusions.

\section{Literature Review}

\subsection{Developing CSR Strategies in India}

Although the Indian economy has grown to become one of the largest in the world, making the country an increasingly important player in the global order, it is still home to the largest number of people living in absolute poverty and the largest number of malnourished children. This contradiction emerges from an unequal distribution of the benefits deriving from economic development, one of the main causes of the numerous social unrests in the country. The awareness of the huge gap between rich and poor has increased the society's expectations also towards the work of companies [25]. In addition to promulgating national guidelines for voluntary social, environmental and economic responsibilities, the Indian government reformed, in fact, Company Law through the Companies Act on 29 August 2013. With the force of law, the latter was issued by the Parliament to "modernize, simplify and make more transparent Indian company law in line with the most advanced legal systems of "Common Law" [25]. One of the obligations placed on companies was to allocate $2 \%$ of the average net profits of the last three years in CSR operations, as well as to engage in a series of activities, including [25]: the promotion of education; eradication of hunger and extreme poverty; the reduction of child mortality; environmental sustainability; the promotion of gender equity and women's empowerment. The combination of regulatory pressure and social pressure have meant that companies have started implementing CSR in a more professional way.

Together with these internal political changes, globalization is a powerful reminder for the implementation of a socially responsible behavior by companies. The rise of global entrepreneurs who make their decisions according to criteria of "socially responsible investments," the growth of the global activism of non-governmental organizations in the control of corporate behavior and the intensified exposure of companies to the judgment of the media have considerably increased the attention to the concept of CSR in both developed and developing countries [9]. However, there are four reasons for differentiating CSR in developing countries from the developed world [13]:

- developing countries are the fastest growing economies, and therefore, the most profitable growth markets for multinational companies; 
- developing countries are those in which the social and environmental crises are generally more acutely felt in the world [26];

- developing countries are those in which globalization, economic growth, investments and economic activities can have the most marked social and environmental impacts [27];

- developing countries present challenges to the implementation of CSR which are altogether very different from those to be addressed in developed ones.

In January 2018, the global network of professional services "Klynveld Peat Marwick Goerdeler" (KPMG) published the "India's CSR reporting survey 2017," a survey that analyzed the CSR activities practiced in India until 30 September 2017. The results are very encouraging: compliance with the regulatory requirements of the Companies Act appears to be solid, and overall spending on social responsibility initiatives has improved compared to previous years (a considerable number of companies have invested in these activities even more than $2 \%$ of the amount required by law). CSR projects seem to increase across the country and start to be conceived by organizations as strategic and many companies now emphasize the social activities in which they engage, promoting them through the websites and social reports published annually [28]. Therefore, it has been decided to focus the study in the Indian context since India, in addition to being the first among developing countries for number of SA 8000 certifications, in the last few years, has proved to develop CSR actions that have led to good results. Therefore, in this context, the study wants to highlight what is the role of the ethical certification, and if this, later, has been a tool to facilitate the development of CSR strategies in India.

\subsection{Reasons for Being SA 8000 Certified}

In a 2009 research, Stigzelius and Mark-Herbert [17] studied the motivations and the advantages that push companies to be SA 8000 certified, identifying," among the main reasons the necessity to satisfy buyers' requests; the desire to identify a strategy aimed at reducing company costs; the implementation of a more quality-oriented system; an increase in motivation and benefits for workers; the improvement of company reputation in the market; the growth of market opportunities; the optimization of the working environment and finally, the improvement of the relationship between workers and top management. The latter factor is also highlighted in the recent study by de Andrade and Bizzo [29], concerning the results of audits of social responsibility management systems according to SA 8000 standard, carried out in 35 units of seven Brazilian organizations. Concerning the necessity to satisfy buyers' requests, this is one of the most important drivers for global exporting countries, the standard, in fact, is considered a prerequisite to enter some markets and networks in developed countries [30]. When Rohitratana [31] examined the textile industry in Thailand, it was discovered that having the SA 8000 standard is not only a way to ensure a desirable work environment for its employees but also an important request to be met. Not owning it, in fact, would represent a difficult obstacle to overcome when local businesses must relate to foreign ones. This aspect was also found in the study focused on the suppliers of the GAP Inc. multinational clothing company, carried out three years later by Henkle [15]; in addition to improving the working environment, enhancing communication between managers and workers, reducing staff turnover and increasing productivity, it emerged that, from the buyers' perspective, the SA 8000 standard offers greater safety than the reliability of suppliers as well as fewer risks associated with human rights violations. SA 8000, in fact, is often requested by American and European buyers who see it as an important tool to achieve greater social compliance. The presence of international voluntary standards such as SA 8000 makes it possible to limit violations in the global supply chain, ensuring health and safety protection as well as regular working hours [32]. More recently, the same conclusion was reached in the work of Koster et al. [33], when, interviewing five SA 8000 adopters (five Indian companies), SA 8000 non-adopters (four companies) and SAI experts (three), they found, unanimously, the important role of current customers as key drivers for SA 8000 adoption. Certification, therefore, can be a means used by manufacturing companies to differentiate themselves, as well as to attract new buyers and increase future orders. 
Ranked in first place of the most certified SA 8000 companies is Italy. From a study carried out by Santos et al. [24], it arises that the drivers that guide the Italian companies to implement the standard are, above all, two: the improvement of the corporate image, in fact, it can be said that the SA 8000 standard constitutes a sort of "social stamp" that allows the enterprise to present itself to the stakeholders with a more reassuring image, on the basis of which it is possible to ask and obtain the trust of those who, directly or indirectly, participate in the company life [34]; and the improvement of the working environment and the relationship with workers. The main benefits obtained, on the other hand, are the reduction of conflicts at work and the attainment of a competitive advantage over competitors [24]. The considerable adhesion to the certification can be partly explained also by the convergence between the social requirements of the standard and the Italian legislative discipline regarding respect for human rights and workers, the healthiness of the workplace and the protection against child exploitation. This, of course, simplifies the certification approval process. For the other countries that follow Italy in the ranking, namely India, China and Vietnam, the certification would represent an additional effort, a willingness of companies to detach from the often negative image of their work contexts that contemplates discrimination and abuse suffered by workers, child exploitation, and environmental risks deriving from amorphous production activities. The adherence to these rules attests the ethical conduct adopted and the commitment to go beyond the legal requirements that, however, in these developing countries, are often inadequate and ineffective to ensure the protection of environmental and human resources [18].

The accredited standard shows that the company is in line with the expectations of social performance and is committed to continuously improve its management systems. Independent supervision combined with periodic surveillance audits by accredited bodies ensure that organizations manage their operations effectively, presenting a low risk of non-compliance with the standard. The risk that may arise is, that the management and members of the organization adhere to the rules of the standard without fully understanding its importance and purpose, thus negating a large part of the efforts and results obtained from the actions undertaken [35]. Additionally, according to Gilbert and Rasche [14], compliance with the SA 8000 rules, as coercion rather than voluntariness, is one of the main problems associated with the standard. In addition to this, being SA 8000 certified can be a major obstacle for companies from a financial point of view; the costs to acquire it vary depending on the number of employees and the characteristics of the workplace, which determine the men and audit days necessary to obtain it [17]. The costs for an audit can range from $\$ 500$ to more than $\$ 1500$ per day (SAAS, 2019). Moreover, in addition to the direct certification costs, some pre-certification activities, such as, improving the structures for workers' health and safety, the revision of wages, the activation of training initiatives and advice are also necessary. Previous research has shown that the high investments needed to implement responsibility standards are often difficult to sustain for small and medium-sized enterprises (SMEs) [15]. Furthermore, it is also important for organizations to integrate SA 8000 with other international standards [36], since combining commitment to quality, the environment and social responsibility is increasingly vital for a solid and lasting business competitiveness. Finally, while a health and safety system based on OHSAS 18001 focuses mainly on the internal environment of the organization, SA 8000 has expanded social responsibility throughout the supply chain [37-39]; hence, to contribute to sustainable development, the company should extend its own social and environmental responsibility from production to all the different actors upstream and downstream of the value chain.

\subsection{The Management of $S A 8000$ in India}

Arevalo and Aravind [40] have devised four models to illustrate the motivations that induce Indian companies to implement CSR initiatives: the "ethical model" is aimed at the welfare of the community, the "statist model" is guided by legal requirements, the "liberal model" focuses on achieving the objectives of the shareholders and finally, the "stakeholder model" which extends its focus to all stakeholders. The last model, followed by the ethical one, is favored by Indian companies which, in general, in their choice to implement socially responsible behaviors prefer moral drivers to 
the economic ones. As for the barriers, however, those found to be more significant were insufficient resources (in economic terms), and lack of management support as well as training.

According to the study conducted by Kanaka Latha [41] and confirmed by those of Govindan et al. [42], the main drivers that lead Indian companies to implement socially responsible activities are: the demand for greater transparency on the part of the stakeholders, the growing interest in consumers, competitiveness in the labor market, investor pressure and relationships with suppliers. The challenges to be faced, however, are: the low participation of the community in the activities of CSR, the need to build local capacities and the lack of transparency. Focusing directly on SA 8000 standard, the study of Pavlikova and Basovnikova [43] aimed at discovering the motivations that push Indian companies to be SA 8000 certified, has identified how the certification represents the commitment of Indian companies towards the fight against child labor. Additionally, Stigzelius et al. [44] had examined the motivations, obstacles and benefits related to the implementation of the SA 8000 standard in seven Indian clothing companies. The motivations that had pushed the companies to certify themselves were the buyers' request, the increase of the company reputation, and the social perspective with the development of an ethical brand, based on fair working conditions. Among the major obstacles encountered, however, there was the ability to effectively communicate the standard at all levels of the organization; in fact, there was a lack of awareness among workers regarding their rights at work and, despite the initial training, a lack of knowledge of the standard, often due to their low level of education and to the origin of rural areas where the presence of unions is very low along with high costs. Greater benefits, were expressed mainly in social terms: thanks to the certification, in fact, the employees felt more respected by the company management, and more often they have a canteen, drinking water, medical services, training, transport as well as adequate safety equipment to limit the risk of accidents at work. The managers of the companies interviewed had not yet obtained significant benefits from the economic point of view but they said they were confident in a growth of their business in the immediate future: they saw the standard as a long-term investment.

Having concluded this necessary premise, as India is the first among developing countries with more certifications in the field of CSR, the aim of the research was to examine the perception of certified clothing companies in relation to the SA 8000 standard and to their ethical and sustainable actions. The questions that arise are therefore:

RQ1: Why do the companies in the Indian textile sector certify according to the SA 8000 standard?

RQ2: How are socially responsible activities managed by the organization?

RQ3: What is their overall assessment of the standard?

\section{Methodology}

The research method for this study is a mixed method based on an embedded design procedure, specifically, that is qualitative and quantitative data are included to answer research questions $[45,46]$. Qualitative data deriving from a multiple case study have been included within a quantitative methodology, developing an experimental design as suggested by Creswell and Clark [47].

According to Creswell [48], a multiple case study method "explores a real-life, contemporary bounded system (a case) or multiple bounded systems (cases) over time, through detailed, in-depth data collection involving multiple sources of information and reports a case description and case themes." As pointed out by several authors, this approach is very useful to understand contemporary phenomena and practices, and to provide background material to actual issues which are still unknown [49]. The Embedded Design permits to mix different data sets at the design level, embedding, in this case, quantitative data within a qualitative methodology, developing a phenomenology design [48].

Case studies, in fact, have been used by researchers not only to test theory [50], but also to render description related to a specific context [51] as well as to develop theory [52].

In this study, given the lack of empirical evidences to our knowledge, it has been decided to adopt it mainly for understanding how the International SA 8000 standard is managed by Indian certified companies, analyzing, in detail, motivations, perceived benefits and barriers to the implementation 
of the standard. The methodology of a multiple case study [53] allows a clearer understanding and characterization of the investigated phenomenon, providing a strong and reliable evidence [54]. Moreover, the multiple case study allows a better generalization of results and also a direct comparison between the similarities and the differences emerged from the investigations carried out on the various phenomena considered. The methodology of the multiple case study chosen is that of a descriptive type, as the research aims to delineate the general and particular features of a given phenomenon [55].

The case study is known as a "triangulated" research strategy. The triangulation of data concerns the use of multiple data collection tools to give greater depth to the study of phenomena from different perspectives [56,57]. Indeed, the adoption of different collection techniques is strongly encouraged for the purposes of the reliability of the information, to limit the distortions and ensure a better quality of the study [58].

\section{Data Collection}

In order to answer the questions underlying the present survey, the use of a mixed method was decided, to obtain quali-quantitative data necessary to develop a multiple case study. According to Yin [50], each case must be selected so that it produces similar results (correspondence between the results of the different cases analyzed-literal replication) or different results but for foreseeable reasons (the cases produce different results but for foreseeable and known circumstances- theoretical replication).

Firms for this study were originally selected according to the following criteria:

- Position: all companies must be located in India;

- Industry: all companies must belong to the textile sector;

- Size and turnover: micro, small and medium-sized companies with a turnover not exceeding 50 million euros and a number of employees less than 250 (European Commission, 2003/361/CE).

As of 15 March 2018, in India, there were 437 certified companies in the textile sector. It was possible to obtain all the information needed to find the companies from the database on the website of the Social Accountability Accreditation Services [19]. Companies from this well-defined sample have been selected using a simple random sampling procedure, searching for their email contact online, since this public list does not include the organization's contact information. Subsequently, we have e-mailed companies for which a contact has been found, asking them for availability to participate in the research. A total number of six companies participated; the decision to examine all six cases respects the lines proposed by Yin [53] according to which the number of units to be analyzed in order to obtain reliable results is between four and twelve: with less than four, it is difficult to build a structured theory, while too many cases make data analysis complicated.

Primary data were collected using a semi-structured interview, composed of 26 questions divided into four sections: the first part reports general questions (turnover, number of employees, reference markets, etc.) with the aim of outlining the profile of the company interviewed. The second part examines the SA 8000 standard by investigating the motivations that have led companies to certify themselves, and the benefits and limitations of the international standard. The third and fourth part, respectively, focus on the present and future commitment of organizations in the field of social responsibility (communication, support for initiatives/associations, etc.). The semi-structured interviews typically lasted $1 \mathrm{~h}$, and were based on an interview protocol: companies were asked to be available to carry out interviews with the person who had the responsibility for developing their CSR strategy and for the implementation of the SA 8000 standard, in order to have the most representative view on the topic for the company. Therefore, for Business 1, the CSR manager was interviewed, for Businesses 3, 4 and 5, their Chief Executive Officers, while Businesses 2 and 6 declared that they did not have a specific figure for this role and that this responsibility was managed by the owner of the company, so they were interviewed. 
What is more, the interview protocol included the subsequent sending of questionnaires by e-mails with five-points Likert scale questions ( $1=$ not at all important; 5 = very important $)$ to better study the personal experience with SA 8000 standard of participating companies, in term of motivations that pushed them to certify themselves and the main benefits and barriers encountered.

Below is a list of the propositions identified thanks to the analysis of the literature and the respective reference literature (Table 1 ):

Table 1. Questionnaire items and reference literature.

\begin{tabular}{|c|c|}
\hline Motivations & Reference literature \\
\hline $\begin{array}{l}\text { To be promoters of a new way of doing business; Competitive advantage over competitors; } \\
\text { Creation of new partnerships; Improvement of the working environment. }\end{array}$ & [41] \\
\hline Greater impact on customers and suppliers; Facilitate hiring. & [39] \\
\hline $\begin{array}{l}\text { Demand from the market; Improvement of the image and reputation; Achievement of } \\
\text { economic benefits; Brand protection. }\end{array}$ & [17] \\
\hline $\begin{array}{l}\text { Presence of incentives at regional or local level; Improvement of the efficiency of business } \\
\text { management. }\end{array}$ & [24] \\
\hline Enterprise risk management. & [15] \\
\hline Benefits & Reference literature \\
\hline Achievement of economic benefits; Improvement of the relationship with employees. & {$[17,26]$} \\
\hline Reduction of risks at work. & {$[15,17]$} \\
\hline Reduction of labor conflicts; Reduction in absenteeism; Increase in staff motivation. & [56] \\
\hline $\begin{array}{l}\text { Improvement of corporate image and reputation; Improvement of productivity and } \\
\text { management efficiency; Achievement of a competitive advantage over competitors. }\end{array}$ & [24] \\
\hline $\begin{array}{l}\text { Increase in transparency towards stakeholders; Improvement in customer loyalty; } \\
\text { Development and consolidation of partnerships; Greater control over the supply chain. }\end{array}$ & [59] \\
\hline Barriers & Reference literature \\
\hline Need of investments. & {$[17,38]$} \\
\hline Management training; Staff training. & [38] \\
\hline $\begin{array}{l}\text { Establishment of an internal health and security supervision; Adaptation of working } \\
\text { conditions; Recruitment of staff with disabilities; Promoting of equal opportunities. }\end{array}$ & {$[17,30]$} \\
\hline
\end{tabular}

Secondary data were gathered owing to a review of the companies' websites and their profiles on different social networks in order to comply with the triangulation principle [57] and to validate the information gathered through the semi-structured interview. Table 2 depicts the profile of respondent businesses.

Table 2. Businesses socio-demographic profile.

\begin{tabular}{|c|c|c|c|c|c|c|}
\hline & Business 1 & Business 2 & Business 3 & Business 4 & Business 5 & Business 6 \\
\hline Income & million \$ & million \$ & million \$ & million \$ & million \$ & million \$ \\
\hline Number of & Large & Large & Medium & Medium & \multirow{2}{*}{$\begin{array}{c}\text { 50-249 } \\
\text { Medium Business } \\
(\mathrm{MB})\end{array}$} & Small \\
\hline employees & $\begin{array}{l}\text { Business } \\
\text { (LB) }\end{array}$ & $\begin{array}{l}\text { Business } \\
\text { (LB) }\end{array}$ & $\begin{array}{l}\text { Business } \\
\text { (MB) }\end{array}$ & $\begin{array}{c}\text { Business } \\
\text { (MB) }\end{array}$ & & $\begin{array}{l}\text { Business } \\
\text { (SB) }\end{array}$ \\
\hline $\begin{array}{l}\text { Geographical } \\
\text { areas in which } \\
\text { the company } \\
\text { operates }\end{array}$ & $\begin{array}{c}\text { Europe, } \\
\text { North/Center/ } \\
\text { South } \\
\text { America }\end{array}$ & $\begin{array}{c}\text { Europe, } \\
\text { North/Center/ } \\
\text { South } \\
\text { America }\end{array}$ & Europe & $\begin{array}{l}\text { Europe, } \\
\text { North } \\
\text { America }\end{array}$ & $\begin{array}{c}\text { Australia, } \\
\text { Europe, } \\
\text { North/Center/ } \\
\text { South America }\end{array}$ & Europe \\
\hline $\begin{array}{l}\text { Certification } \\
\text { period for SA } \\
8000\end{array}$ & $\begin{array}{c}13 \text { years } \\
(2005)\end{array}$ & $\begin{array}{l}4 \text { years } \\
(2014)\end{array}$ & $\begin{array}{c}1 \text { years } \\
(2017)\end{array}$ & $\begin{array}{l}10 \text { years } \\
(2008)\end{array}$ & $\begin{array}{c}3 \text { years } \\
(2015)\end{array}$ & $\begin{array}{c}6 \text { years } \\
(2012)\end{array}$ \\
\hline
\end{tabular}




\section{Results and Discussion}

Analyzing the motivations behind the certification (Table 3), all the companies agreed to consider the possibility of having a better impact on customers and suppliers, to improve the working environment, but also to improve their image and reputation, indicating that they were encouraged to obtain certification from a market request. This is in line with what has been found in previous studies of $[17,41,43]$. It should be underlined, the emergence from interviews, of a factor not detected by previous research, that is, the intent to use the standard to improve the management and the efficiency of the company. This element, not underlined previously on literature concerning CSR strategies in developing countries, raises how Indian companies are using this tool not only to have external benefits related to image and customer/supplier approval, but they make use of the certification with a will to grow internally and evolve to obtain a competitive advantage due to its efficiency. Moreover, Business 1 is the only participant to have been considered as indifferent to the possibility of having a competitive advantage over competitors, considered as important by other companies. It appeared that, since they were a large company with a high turnover, they were less interested in competitors, considering their position was already well established in their reference markets. The creation of new partnerships, the promotion of a new way of doing business and the management of business risk have also been considered important by most companies: the only one that has given a discordant opinion is the small company (Business 6), as it declared to be more oriented to obtain external benefits from SA 8000 standard related to their image. Therefore, it is possible to consider as relevant, the propositions related to the will to deviate from socially irresponsible behaviors and to improve the company competitiveness as well as favoring business relationships, as underlined by Pavlíková and Basovníková [43]. As for the presence of incentives at a regional or local level, this factor is not perceived by companies as fundamental in the decision to implement the SA 8000 management system; same as for the achievement of economic benefits. A first observation related to this result is that despite India being the first country in the world to make CSR mandatory, following an amendment to the Companies Act, 2013 in April 2014, and that companies received incentives for developing CSR strategies, companies had the will to underline that this did not influence their intention to move towards the ethical certification. Secondly, this is linked to what has been identified in the literature, namely that the drivers of SA 8000 are more of a moral than economic type [40].

Table 3. Motivations that pushed companies to be SA 8000 certified.

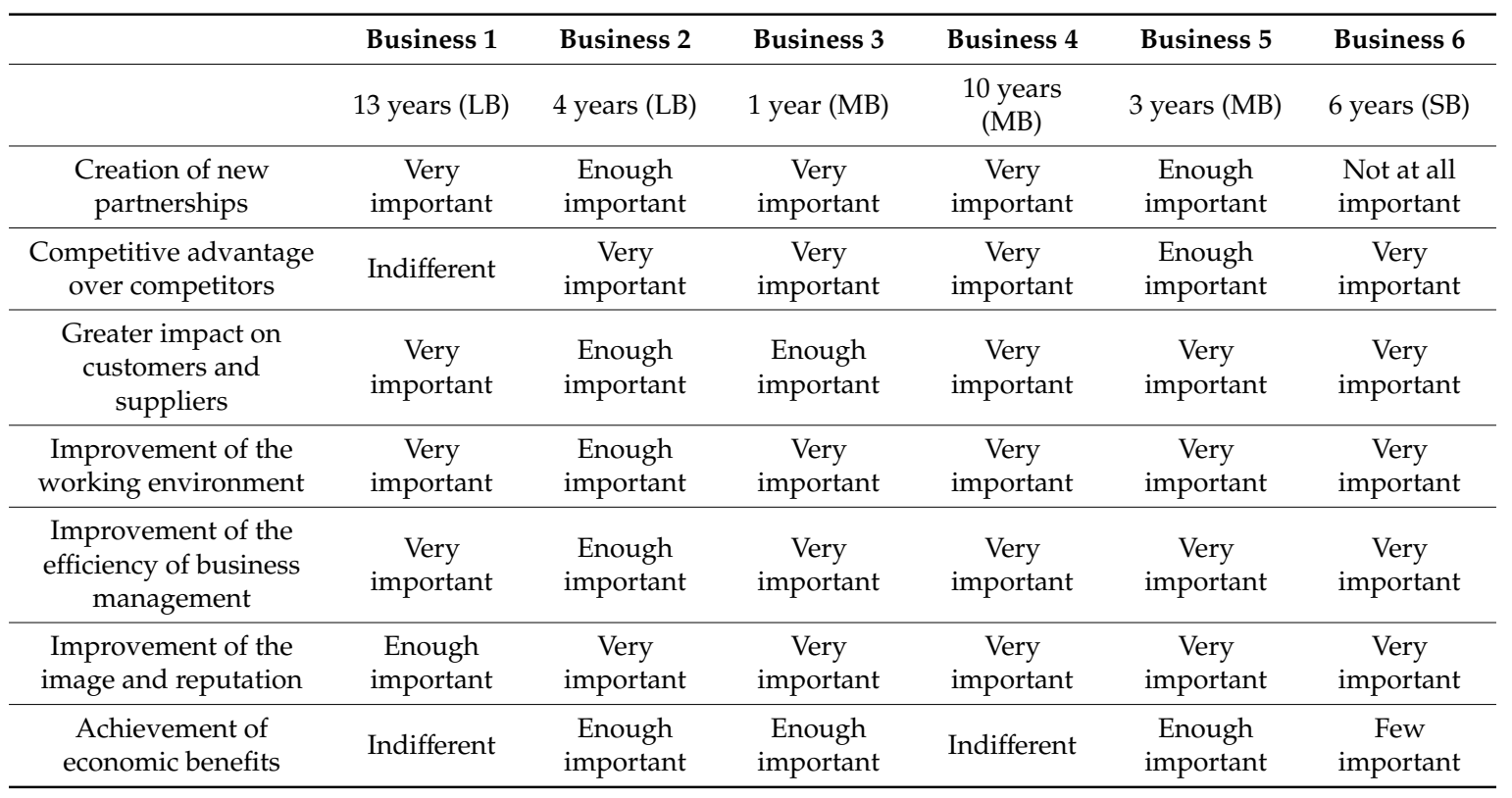


Table 3. Cont.

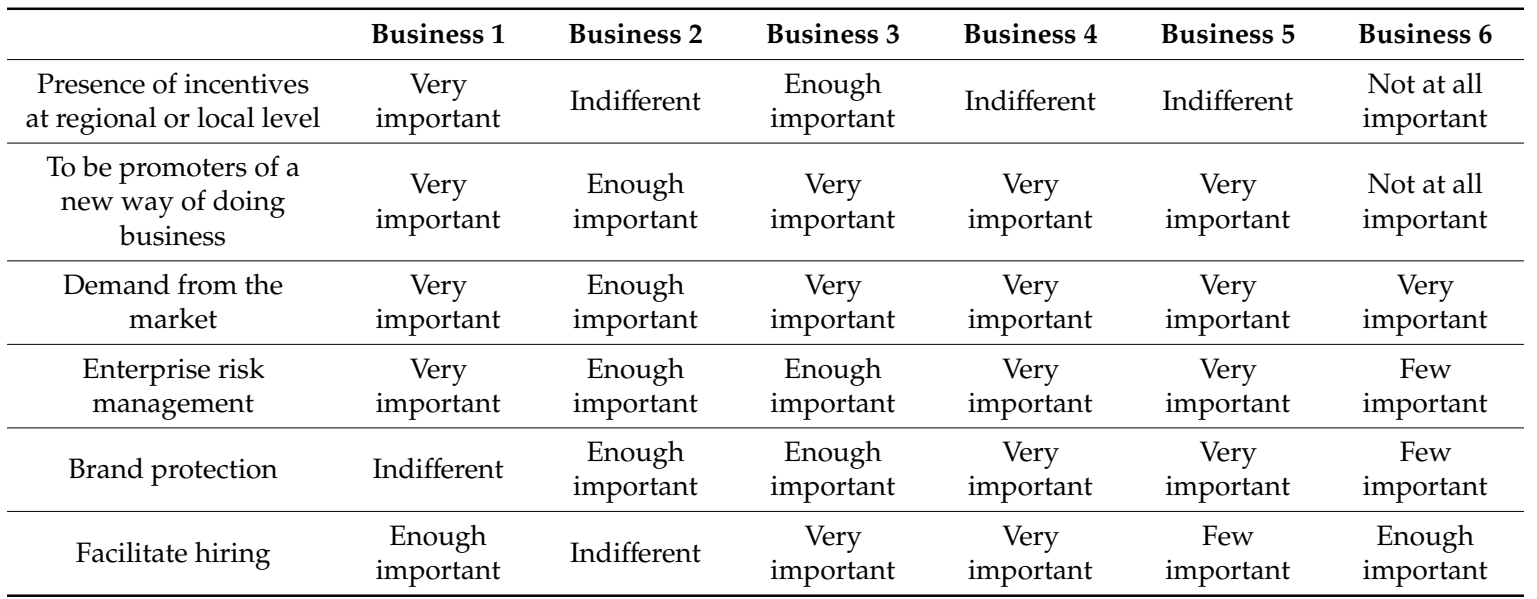

As for the main benefits (Table 4), the factors considered important from all the participants were the increase in staff motivation, the increase in transparency towards stakeholders, the achievement of a competitive advantage over competitors, greater control over the supply chain, the improvement of consumer loyalty, of the relationship with employees, of the image and reputation of the company and the possibility to reduce risks at work. The KPMG report [39] highlighted that in India, there is improved transparency and compliance across companies. Close to $99 \%$ of the 100 companies surveyed successfully implemented their planned CSR policy in 2018, up from 55\% in 2014-15 and over 90\% of companies have stand-alone CSR committees. These committees are run by independent directors, of which $64 \%$ include at least one woman.

Table 4. Benefits of being SA 8000 certified.

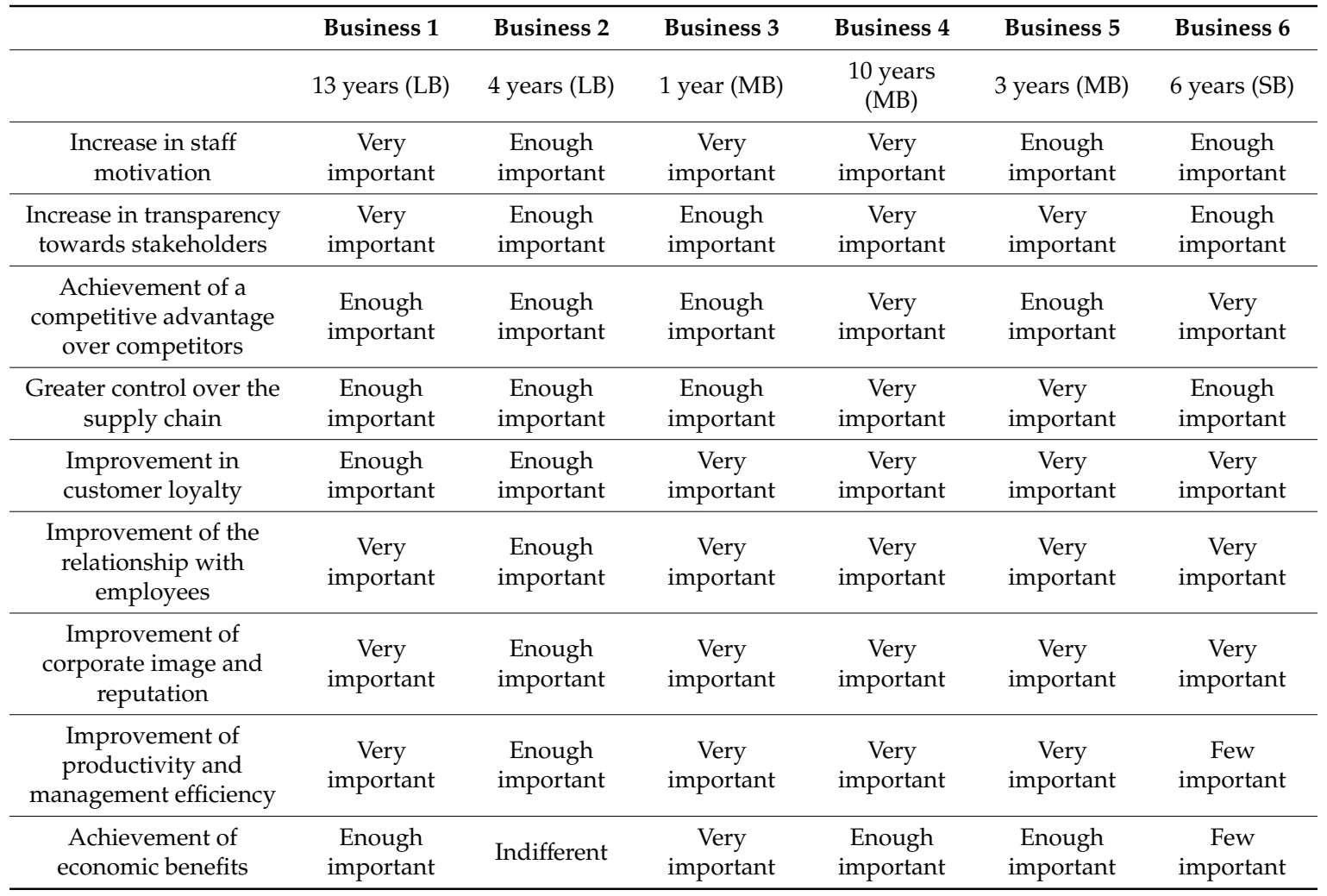


Table 4. Cont.

\begin{tabular}{ccccccc}
\hline & Business 1 & Business 2 & Business 3 & Business 4 & Business 5 & Business 6 \\
\hline $\begin{array}{c}\text { Reduction of labor } \\
\text { conflicts }\end{array}$ & Indifferent & Indifferent & $\begin{array}{c}\text { Enough } \\
\text { important }\end{array}$ & $\begin{array}{c}\text { Very } \\
\text { important }\end{array}$ & $\begin{array}{c}\text { Very } \\
\text { important }\end{array}$ & $\begin{array}{c}\text { Enough } \\
\text { important }\end{array}$ \\
\hline $\begin{array}{c}\text { Reduction of risks at } \\
\text { work }\end{array}$ & $\begin{array}{c}\text { Very } \\
\text { important }\end{array}$ & $\begin{array}{c}\text { Enough } \\
\text { important }\end{array}$ & $\begin{array}{c}\text { Very } \\
\text { important }\end{array}$ & $\begin{array}{c}\text { Very } \\
\text { important }\end{array}$ & $\begin{array}{c}\text { Very } \\
\text { important }\end{array}$ & $\begin{array}{c}\text { Enough } \\
\text { important }\end{array}$ \\
\hline $\begin{array}{c}\text { Reduction in } \\
\text { absenteeism }\end{array}$ & Indifferent & Indifferent & $\begin{array}{c}\text { Very } \\
\text { important }\end{array}$ & $\begin{array}{c}\text { Very } \\
\text { important }\end{array}$ & $\begin{array}{c}\text { Enough } \\
\text { important }\end{array}$ & $\begin{array}{c}\text { Few } \\
\text { important }\end{array}$ \\
\hline $\begin{array}{c}\text { Development and } \\
\text { consolidation of } \\
\text { partnerships }\end{array}$ & $\begin{array}{c}\text { Enough } \\
\text { important }\end{array}$ & $\begin{array}{c}\text { Enough } \\
\text { important }\end{array}$ & $\begin{array}{c}\text { Enough } \\
\text { important }\end{array}$ & $\begin{array}{c}\text { Very } \\
\text { important }\end{array}$ & $\begin{array}{c}\text { Enough } \\
\text { important }\end{array}$ & $\begin{array}{c}\text { Not at all } \\
\text { important }\end{array}$ \\
\hline
\end{tabular}

The attribution of importance to these factors confirms what was previously defined in the literature panorama about SA 8000 [17,59]. Added to these statements, there is the conquest of benefits such as increased productivity and management efficiency, together with the development and consolidation of new partnerships, factors considered important by all companies, except for Business 6. Despite the desire to increase the efficiency of company management as one of Business 6's motivations that led it to become certified in its six years of certification; during the interview, they declared that they have not yet managed to achieve this goal, due to spending a lot of time receiving external benefits from it, such as the achievement of a competitive advantage over competitors.

On the other end, it cannot be said with absolute certainty that the reduction of absenteeism is one of the benefits directly obtained through the implementation of the SA 8000 standard as highlighted only by half of the companies. Therefore, what was stated by Dhanesh [60] cannot be confirmed.

Regarding the barriers (see Table 5), those considered most significant by all companies were: the training of management and staff, the need to establish internal supervision for health and safety, the promotion of equal opportunities and the need to adapt companies' working conditions. These answers allow to confirm the main limitations found in previous research $[17,40]$. Even the need of investments has been judged by four companies out of six as an important obstacle to the implementation of the standard; this is not seen as relevant by Business 1, for its huge investment capacity, but also by Business 6, which has a much lower turnover, but declared to consider the money spent on CSR activities as a profitable investment and therefore, does not consider it as a barrier. Despite the need for investment as seen sometimes as an obstacle, it seems that in 2018, in India, the average amount spent on CSR stood at Rs 81 crore, up 9\% from 2016, and that CSR spending by Indian companies was heavily skewed towards education and healthcare [39]. This shows the will of Indian companies to overcome the barriers faced.

As regards to the management of CSR activities discussed during the interviews with companies' managers and summarized in Table 6, almost all companies have a delegated person to the management of matters relating to social responsibility. In medium-sized companies, the one who deals with these issues is the Chief Executive Officer (CEO), while in large companies, there is an ad hoc figure. Regarding additional standards held, it is Business 2 who owns the major number of certifications, having developed an Integrated Management System (IMS), for the management of Quality, Environmental, Health, Safety and Social issues, despite that they are the same to declare not having a CSR manager. The ISO 9001 standard is also owned by Business 5 and 1 . The latter, moreover, has the "Worldwide Responsible Accredited Production" (WRAP) standard, the program for the producers of clothing, footwear and accessories that aims to ensure safe, legal and ethically correct production processes (www.wrapcompliance.org); Business 4 also owns this standard, while Businesses 3 and 6 have only the SA 8000 one. Furthermore, in March 2018, the International Organization for Standardization promulgated the new management system standard for health and safety at work defined by the ISO 45001. The interviews revealed that four out of six companies have the will to be ISO 45001 certified in the future without abandoning the SA 8000 standard, but maintaining both standards. Only Company 2 and Company 6 confidently stated that they will not be certified. 
Table 5. Barriers to SA 8000 certification.

\begin{tabular}{|c|c|c|c|c|c|c|}
\hline & Business 1 & Business 2 & Business 3 & Business 4 & Business 5 & Business 6 \\
\hline & 13 years (LB) & 4 years (LB) & 1 year $(\mathrm{MB})$ & $\begin{array}{l}10 \text { years } \\
(\mathrm{MB})\end{array}$ & 3 years $(\mathrm{MB})$ & 6 years $(\mathrm{SB})$ \\
\hline Need of investment & Indifferent & $\begin{array}{l}\text { Enough } \\
\text { important }\end{array}$ & $\begin{array}{c}\text { Very } \\
\text { important }\end{array}$ & $\begin{array}{c}\text { Very } \\
\text { important }\end{array}$ & $\begin{array}{l}\text { Enough } \\
\text { important }\end{array}$ & Indifferent \\
\hline Management training & $\begin{array}{l}\text { Enough } \\
\text { important }\end{array}$ & $\begin{array}{l}\text { Enough } \\
\text { important }\end{array}$ & $\begin{array}{c}\text { Very } \\
\text { important }\end{array}$ & $\begin{array}{c}\text { Very } \\
\text { important }\end{array}$ & $\begin{array}{c}\text { Very } \\
\text { important }\end{array}$ & $\begin{array}{l}\text { Enough } \\
\text { important }\end{array}$ \\
\hline Staff training & $\begin{array}{l}\text { Enough } \\
\text { important }\end{array}$ & $\begin{array}{l}\text { Enough } \\
\text { important }\end{array}$ & $\begin{array}{c}\text { Very } \\
\text { important }\end{array}$ & $\begin{array}{c}\text { Very } \\
\text { important }\end{array}$ & $\begin{array}{c}\text { Very } \\
\text { important }\end{array}$ & $\begin{array}{l}\text { Enough } \\
\text { important }\end{array}$ \\
\hline $\begin{array}{l}\text { Establishment of an } \\
\text { internal health and } \\
\text { security supervision }\end{array}$ & $\begin{array}{c}\text { Very } \\
\text { important }\end{array}$ & $\begin{array}{l}\text { Enough } \\
\text { important }\end{array}$ & $\begin{array}{c}\text { Very } \\
\text { important }\end{array}$ & $\begin{array}{c}\text { Very } \\
\text { important }\end{array}$ & $\begin{array}{l}\text { Enough } \\
\text { important }\end{array}$ & $\begin{array}{l}\text { Enough } \\
\text { important }\end{array}$ \\
\hline $\begin{array}{l}\text { Recruitment of staff } \\
\text { with disabilities }\end{array}$ & Indifferent & Indifferent & $\begin{array}{c}\text { Very } \\
\text { important }\end{array}$ & $\begin{array}{c}\text { Very } \\
\text { important }\end{array}$ & Indifferent & $\begin{array}{c}\text { Very } \\
\text { important }\end{array}$ \\
\hline $\begin{array}{l}\text { Promoting of equal } \\
\text { opportunities }\end{array}$ & $\begin{array}{c}\text { Very } \\
\text { important }\end{array}$ & $\begin{array}{l}\text { Enough } \\
\text { important }\end{array}$ & $\begin{array}{c}\text { Very } \\
\text { important }\end{array}$ & $\begin{array}{c}\text { Very } \\
\text { important }\end{array}$ & $\begin{array}{c}\text { Very } \\
\text { important }\end{array}$ & $\begin{array}{l}\text { Enough } \\
\text { important }\end{array}$ \\
\hline $\begin{array}{l}\text { Adaptation of working } \\
\text { conditions }\end{array}$ & $\begin{array}{c}\text { Very } \\
\text { important }\end{array}$ & $\begin{array}{l}\text { Enough } \\
\text { important }\end{array}$ & $\begin{array}{c}\text { Very } \\
\text { important }\end{array}$ & $\begin{array}{c}\text { Very } \\
\text { important }\end{array}$ & $\begin{array}{c}\text { Very } \\
\text { important }\end{array}$ & $\begin{array}{c}\text { Enough } \\
\text { important }\end{array}$ \\
\hline
\end{tabular}

Table 6. Businesses' social commitment.

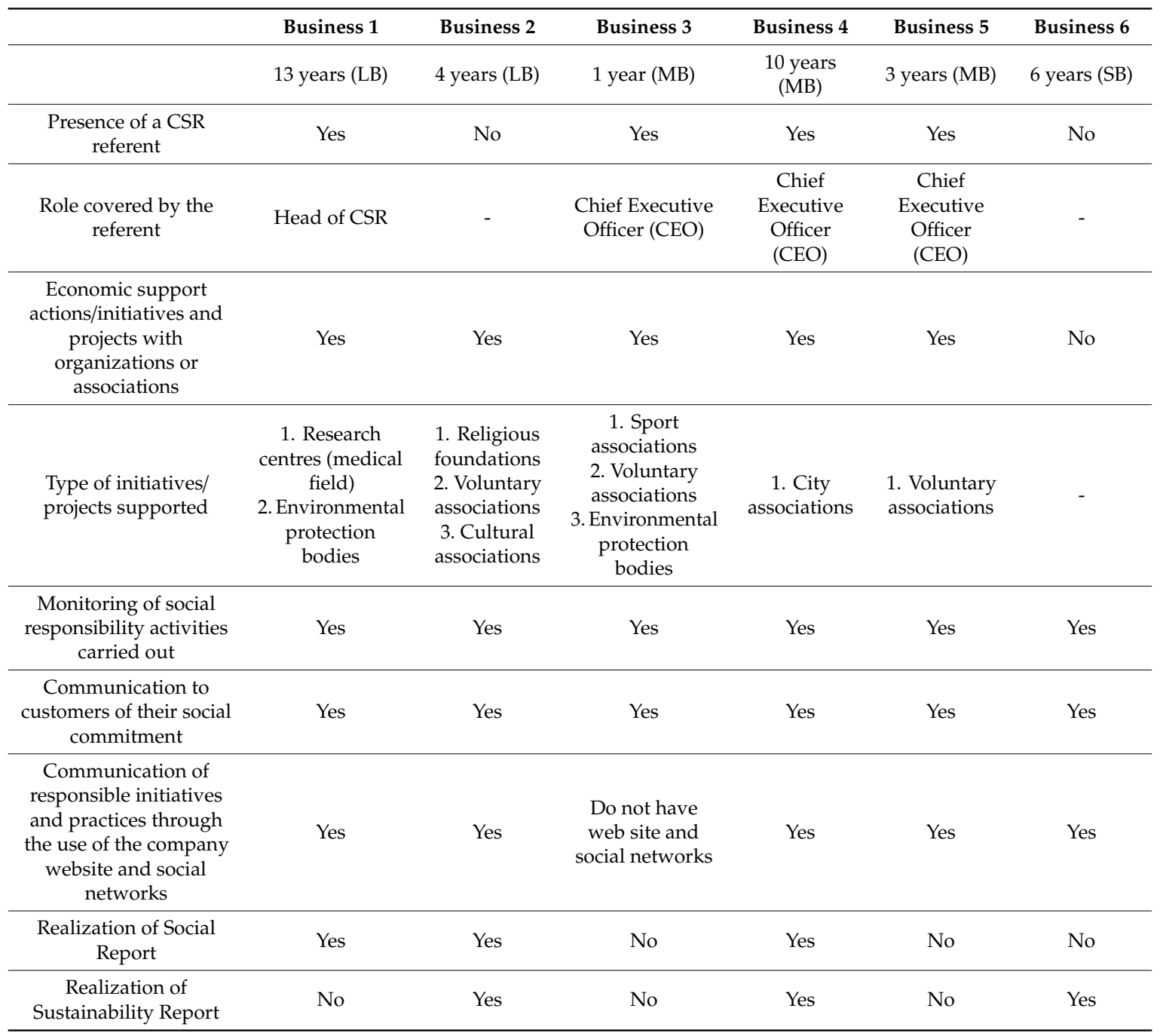


Table 6. Cont.

\begin{tabular}{|c|c|c|c|c|c|c|}
\hline & Business 1 & Business 2 & Business 3 & Business 4 & Business 5 & Business 6 \\
\hline $\begin{array}{l}\text { Presence of other } \\
\text { standard owned }\end{array}$ & $\begin{array}{l}\text { ISO } 9001 \\
\text { WRAP }\end{array}$ & $\begin{array}{c}\text { EMAS III, } \\
\text { ISO 9001, } \\
\text { ISO 14001, } \\
\text { OHSAS } \\
18001\end{array}$ & No & WRAP & ISO 9001 & No \\
\hline $\begin{array}{l}\text { Global evaluation of the } \\
\text { SA } 8000 \text { standard as } \\
\text { CSR tool }\end{array}$ & Very useful & $\begin{array}{l}\text { Enough } \\
\text { useful }\end{array}$ & Enough useful & Very useful & Very useful & Very useful \\
\hline
\end{tabular}

In developing its sustainable strategies, Business 6 is the only one to affirm that it has not economically supported any type of association, initiative or project of a social nature in the last year, and to consider "not at all important" the commitment to support these initiatives in the future. Although not all companies have a reference person in the field of CSR, they all say they still carry out a continuous monitoring of the socially responsible activities they perform. Furthermore, each unit of analysis declares that it is committed to communicating its social commitment and the initiatives it intends to undertake (or has already undertaken) in the ethical field. This is the best practice as identified in the literature [61]. In India, the directive issued by Securities and Exchange Board of India (SEBI) for CSR evaluation in 2011 was the first step towards mandating CSR reporting [62]. Chaudhri and Wang [63], in their study, observe that transparent CSR communication can serve as a forum for constructive dialogue with the stakeholders resulting in development of mutual trust and long-term collaborations.

In addition, all the companies, with the exception of Business 3, declared to have a company website or a profile on social networks that they use as a means to spread their commitment to the pursuit of these disciplines and practices. As confirmed by the study of Kumar and Kidwai [64], Internet for CSR communication allows "an ongoing and interactive process rather than a static annual product."

Despite this, only half of the sample drew up the Social Report and the Sustainability Report, two important documents with which companies should communicate periodically and voluntarily the outcomes of their activities, not limited only to financial and accounting [65]. The only ones to set them both are Business 2 and Business 4. During the interviews, it emerged that it is easier and leaner for companies to communicate their CSR strategies through the web than to draft such documents.

To conclude, it is possible to state that all companies have assessed the certification to be quite or very convenient for their businesses, therefore, being satisfied of their choice. It is the small company (Business 6) that has given the most conflicting answers compared to other companies. It can be deduced that in choosing to certify this business was mostly driven by the desire to align with the needs of their market and stakeholders that require ever more transparency and adaptation to certain ethical and social standards as underlined by Zhu et al. [66]. Having denied the intention to create new partnerships, it could be assumed that its main purpose is solely to not lose current customers.

\section{Conclusions, Practical Implications and Limitation of the Research}

The purpose of this research was to examine the perception of companies in the Indian textile sector towards CSR, in particular towards one of the most widespread and important certifications in this field: the SA 8000 standard. The decision to focus on the Indian market was taken after examining the ranking of nations based on the number of companies in possession of the standard: India was in second place after Italy and in first place among the developing countries [19]. Moreover, in the last few years, India has developed CSR strategies obtaining good results; therefore, using India as reference among developing countries to consider what is the role of the SA 8000 standard would have been of greatest interest. 
The study showed that one of the main reasons of being SA 8000 certified is the willingness to satisfy the request for greater transparency on the part of stakeholders (customers, suppliers, investors, etc.) and the market in general. In fact, in order to engage more sustainable relationships with companies located in these countries, multinational companies often require them to align themselves with certain "Codes of Conduct." The many scandals ended up in the spotlight (originated by unethical behavior) along with increasingly informed and attentive consumers, are, in fact, now a strong incentive not to continue considering developing countries only as a source of raw materials and low-cost labor, but rather as real strategic partners [67].

Certifying SA 8000, Indian textile companies want to be promoters of a new way of doing business, more sustainable and ethical than what is present in the collective imagination [68]. To conclude, by favoring a more effective management of business risk, practicing socially responsible behaviors allow companies to comply more closely with legal obligations (limiting the possibility of incurring penalties), identifying in advance the threats and opportunities deriving from market changes, but also to align with the ethical expectations of the community obtaining esteem and respect $[17,24,43]$. India, as the developing country with the highest number of SA 8000 certified organizations, could be seen as a point of reference and a model for all companies in the developing countries that want to implement the standard.

This study contributed, in a practical way, to presenting results and useful data so that managers of social responsibility in several organizations can evaluate the difficulties encountered in managing their businesses and define preventive and effective actions. The implementation of the SA 8000 standard could be an effective tool for managers to improve a socially responsible international image of the business, develop international partnerships and obtain new consumers.

The standard may provide enough evidence to consumers regarding the sensitivity of manufacturers of goods, or providers of services to social issues. Conversely, from the producer's point of view, the standard may be the instrument to inform the market regarding its strategy and behavior on these issues. Often, the standard is adopted in association with other important international ones both assuring legal and ethically correct production processes, but this also demonstrates companies' commitment to the quality management of their own business processes, attention to the environment and to safety in their workplaces. Therefore, the study demonstrates how SA 8000, included in an integrated system of standards, could be easily managed by a company and used by managers to further strengthen their position at an international level.

Future studies could extend the research by involving other important stakeholders such as workers and suppliers, in order to know their points of view regarding these issues, and eventually assess whether they are in line with those of entrepreneurs. Studies could be performed in other sectors (interviewing, for example, service companies rather than manufacturing) comparing the perceptions related to CSR and the use of SA 8000 among those different companies. Finally, it would be an interesting object of study to analyze if and how much religious belief or government policies influence the choice to practice socially responsible behavior in countries.

Of course, the multiple case study presents some limits: it should be noted that the results of this research are not characterized by their generalizability but rather to provide empirical evidence aimed at confirming, expanding and/or (re-) formulating the theoretical propositions from which to start, as also stated by Hodkinson and Hodkinson, [69].

Author Contributions: The work is the result of the fair collaboration of all the authors. F.M. supervised the research process and was responsible of the literature analysis. L.B. collected, and curated the data and defined the methodology. F.M. and L.B. discussed the conceptualization and the results interpretation and drew their conclusions. All authors have read and agreed to the published version of the manuscript.

Funding: This research received no external funding.

Conflicts of Interest: The authors declare no conflict of interest. 


\section{References}

1. Castka, P.; Bamber, C.J.; Bamber, D.J.; Sharp, J.M. Integrating corporate social responsibility (CSR) into ISO management systems-In search of a feasible CSR management system framework. TQM Mag. 2004, 16, 216-224. [CrossRef]

2. Bhadra, S.K. An alternative Stakeholder Management Tool. Conflict-Consensus-Collaboration. Parikalpana KIIT J. Manag. 2013, 9, 1-11.

3. Freeman, R.E. Divergent stakeholder theory. Acad. Manag. Rev. 1999, 24, 233-236. [CrossRef]

4. Peng, L.M. Internal corporate social responsibility: An overview. Aust. J. Basic Appl. Sci. 2014, 8, 18-29.

5. Carroll, A.B. Corporate social responsibility: Evolution of a definitional construct. Bus. Soc. 1999, 38, 268-295. [CrossRef]

6. United Nations (UN). Transforming Our World: The 2030 Agenda for Sustainable Development; United Nations: New York, NY, USA, 2015.

7. CSRwire. About CSRwire. 2003. Available online: http://www.csrwire.com/page.cgi/about.html (accessed on 17 September 2019).

8. Dahlsrud, A. How corporate social responsibility is defined: An analysis of 37 definitions. Corp. Soc. Responsib. Environ. Manag. 2008, 15, 1-13. [CrossRef]

9. Matten, D.; Moon, J. "Implicit" and "explicit" CSR: A conceptual framework for a comparative understanding of corporate social responsibility. Acad. Manag. Rev. 2008, 33, 404-424. [CrossRef]

10. Brammer, S.; Pavelin, S. Corporate community contributions in the United Kingdom and the United States. J. Bus. Ethics 2005, 56, 15-26. [CrossRef]

11. Crane, A.; Matten, D.; Spence, L.J. Corporate Social Responsibility: Readings and Cases in a Global Context 2/e; Routledge: Abingdon, UK, 2013; pp. 3-26.

12. Napoli, M. La Responsabilità Sociale Delle Imprese; Vita e Pensiero: Milano, Italy, 2005.

13. Webb, T. Is Asian corporate governance improving? Ethical Corp. 2006, 25-26.

14. Gilbert, D.U.; Rasche, A. Discourse ethics and social accountability-The ethics of SA 8000. Bus. Ethics Q. 2007, 17, 187-216. [CrossRef]

15. Henkle, D. Gap Inc. sees supplier ownership of compliance with workplace standards as an essential element of socially responsible sourcing. J. Organ. Excell. 2005, 25, 17-25. [CrossRef]

16. Mamic, I. Implementing Codes of Conduct: How Businesses Manage Social Performance in Global Supply Chains; International Labour Organization (ILO) in Association with Greenleaf Publishing: Sheffield, UK, 2004.

17. Stigzelius, I.; Mark-Herbert, C. Tailoring corporate responsibility to suppliers: Managing SA 8000 in Indian garment manufacturing. Scand. J. Manag. 2009, 25, 46-56. [CrossRef]

18. Murmura, F.; Bravi, L.; Palazzi, F. Evaluating companies' commitment to corporate social responsibility: Perceptions of the SA 8000 standard. J. Clean. Prod. 2017, 164, 1406-1418. [CrossRef]

19. Social Accountability Accreditation Services (SAAS). SA8000 Certified Organisations. 2019. Available online: http://www.saasaccreditation.org/certfacilitieslist (accessed on 5 February 2019).

20. Llach, J.; Marimon, F.; del Mar Alonso-Almeida, M. Social Accountability 8000 standard certification: Analysis of worldwide diffusion. J. Clean. Prod. 2015, 93, 288-298. [CrossRef]

21. Sartor, M.; Orzes, G.; Di Mauro, C.; Ebrahimpour, M.; Nassimbeni, G. The SA8000 social certification standard: Literature review and theory-based research agenda. Int. J. Prod. Econ. 2016, 175, 164-181. [CrossRef]

22. Arminen, H.; Puumalainen, K.; Pätäri, S.; Fellnhofer, K. Corporate social performance: Inter-industry and international differences. J. Clean. Prod. 2018, 177, 426-437. [CrossRef]

23. Zhu, Q.; Lai, K.H. Enhancing supply chain operations with extended corporate social responsibility practices by multinational enterprises: Social capital perspective from Chinese suppliers. Int. J. Prod. Econ. 2019, 213, 1-12. [CrossRef]

24. Santos, G.; Murmura, F.; Bravi, L. SA 8000 as a Tool for a Sustainable Development Strategy. Corp. Soc. Responsib. Environ. Manag. 2018, 25, 95-105. [CrossRef]

25. Confederation of Indian Industry (CII). Handbook on Corporate Social Responsibility in India. PricewaterhouseCoopers. 2013. Available online: https:/www.pwc.in/assets/pdfs/publications/2013/ handbook-on-corporate-social-responsibility-in-india.pdf (accessed on 25 April 2019).

26. United Nations Development Programme (UNDP). Beyond Scarcity: Power, Poverty and the Global Water Crisis; UNDP: Bruxelles, Belgium, 2006. 
27. World Bank. World Development Report 2007: Development and the Next Generation; World Bank: Washington, DC, USA, 2006.

28. India Filings. Companies Act. 2013. Available online: https://www.indiafilings.com/learn/wp-content/ uploads/2014/03/Companies-Act-2013.pdf (accessed on 4 February 2019).

29. de Andrade, V.F.; Bizzo, W.A. Corporate social responsibility in Brazil according to SA 8000: Case studies and the correlation with the supply chain. J. Clean. Prod. 2019, 210, 1022-1032. [CrossRef]

30. Castka, P.; Balzarova, M.A. The impact of ISO 9000 and ISO 14,000 on standardisation of social responsibility-An inside perspective. Int. J. Prod. Econ. 2008, 113, 74-87. [CrossRef]

31. Rohitratana, K. SA 8000: A tool to improve quality of life. Manag. Audit. J. 2002, 17, 60-64. [CrossRef]

32. Palley, T.I. Labour standards, democracy and wages: Some cross-country evidence. J. Int. Dev. 2005, 17, 883-898. [CrossRef]

33. Koster, M.; Vos, B.; van der Valk, W. Drivers and barriers for adoption of a leading social management standard (SA8000) in developing economies. Int. J. Phys. Distrib. Logist. Manag. 2019, 49, 534-551. [CrossRef]

34. Sciarelli, S. Etica e Responsabilità Sociale nell'impresa; Giuffrè Editore: Torino, Italy, 2007.

35. De Colle, S.; Henriques, A.; Sarasvathy, S. The paradox of corporate social responsibility standards. J. Bus. Ethics 2014, 125, 177-191. [CrossRef]

36. Murmura, F.; Bravi, L. Exploring customers' perceptions about quality management systems: An empirical study in Italy. Total. Qual. Manag. Bus. Excell. 2018, 29, 1466-1481. [CrossRef]

37. Jørgensen, T.H.; Remmen, A.; Mellado, M.D. Integrated management systems-three different levels of integration. J. Clean. Prod. 2006, 14, 713-722. [CrossRef]

38. Pero, E. La Responsabilità Sociale d'Impresa in India, Fiscalità e Commercio Internazionale; UTET Giuridica: Milano, Italy, 2015.

39. Klynveld Peat Marwick Goerdeler (KPMG). India's CSR Reporting Survey. 2017. Available online: https://assets.kpmg.com/content/dam/kpmg/in/pdf/2018/02/CSR-Survey-Report.pdf (accessed on 7 July 2019).

40. Arevalo, J.A.; Aravind, D. Corporate social responsibility practices in India: Approach, drivers, and barriers Corporate Governance. Int. J. Bus. Soc. 2011, 11, 399-414. [CrossRef]

41. Kanaka Latha, V. Corporate Social Responsibility in India: Issues and Challenges. Int. J. Adv. Res. Innov. Ideas Educ. 2017, 3.

42. Govindan, K.; Shankar, M.; Kannan, D. Supplier selection based on corporate social responsibility practices. Int. J. Prod. Econ. 2018, 200, 353-379. [CrossRef]

43. Pavlíková, E.A.; Basovníková, M. Certification of Corporate Social Responsibility. The Case Study of India. Acta Univ. Agric. et Silvic. Mendel. Brun. 2014, 62, 605-611. [CrossRef]

44. Stigzelius, I.; Fredricsdotter, L.; Mark-Herbert, C. Implementation of SA8000 in Indian Garment Manufacturing. In Working Paper Presented at the Corporate Responsibility Research Conference; Trinity College: Dublin, Ireland, 2006.

45. Caracelli, V.J.; Greene, J.C. Data analysis strategies for mixed-method evaluation designs. Educ. Eval. Policy Anal. 1993, 15, 195-207. [CrossRef]

46. Yin, R.K. Case Study Research and Applications: Design and Methods; Sage Publishing: Beverly Hills, CA, USA, 2017.

47. Creswell, J.W.; Clark, V.L.P. Designing and Conducting Mixed Methods Research; SAGE Publications: Thousand Oaks, CA, USA, 2007.

48. Creswell, J.W. Qualitative Inquiry and Research Design: Choosing Among Five Approaches; Sage: Thousand Oaks, CA, USA, 2013.

49. Gummesson, E. Total Relationship Marketing, 2nd ed.; Butterworth Heinemann: Oxford, UK, 2002.

50. Pinfield, L.T. A field evaluation of perspectives on organizational decision making. Adm. Sci. Q. 1986, 31, 365-388. [CrossRef]

51. Kidder, T. Soul of a New Machine; Avon: New York, NY, USA, 1982.

52. Eisenhardt, K.M.; Graebner, M.E. Theory building from cases: Opportunities and challenges. Acad. Manag. J. 2007, 50, 25-32. [CrossRef]

53. Yin, R.K. Case Study Research: Design and Methods, 3rd ed.; Sage: Thousand Oaks, CA, USA, 2003.

54. Baxter, P.; Jack, S. Qualitative case study methodology: Study design and implementation for novice researchers. Qual. Rep. 2008, 13, 544-559. 
55. Bertazzaghi, E.; Guerci, M.; Vinante, M. La Valutazione Stakeholder-Based Della Formazione Continua. Modelli, Processi, Strumenti; Franco Angeli: Milano, Italy, 2010.

56. Allodola, V.F. Metodi di ricerca qualitativa in Medical Education: Approcci, strumenti e considerazioni di rigore scientifico. Educ. Sci. Soc. 2014, 5, 121-144.

57. Denzin, N. The Research Act; Prentice Hall: Upper Saddle River, NJ, USA, 1984.

58. Guasti, L. Apprendimento e Insegnamento: Saggi Sul Metodo; Vita e Pensiero: Milano, Italy, 2002.

59. Prasad, V.V.S.K. CSR Initiatives of Indian Companies-A Study; The Hindu College-MBA: Andhra Pradesh, India, 2009.

60. Dhanesh, G.S. CSR as organization-employee relationship management strategy: A case study of socially responsible information technology companies in India. Manag. Commun. Q. 2014, 28, 130-149. [CrossRef]

61. Kim, S.; Ji, Y. Chinese consumers' expectations of corporate communication on CSR and sustainability. Corp. Soc. Responsib. Environ. Manag. 2017, 24, 570-588. [CrossRef]

62. Biswas, U.A.; Garg, S.; Singh, A. The need for regulatory intervention in corporate social responsibility in India: Evidence from corporate social disclosures. Int. J. Indian Cult. Bus. Manag. 2016, 12, $293-317$. [CrossRef]

63. Chaudhri, V.; Wang, J. Communicating corporate social responsibility on the internet a case study of the top 100 information technology companies in India. Manag. Commun. Q. 2007, 21, 232-247. [CrossRef]

64. Kumar, S.; Kidwai, A. CSR disclosures and transparency among top Indian companies. Int. J. Indian Cult. Bus. Manag. 2018, 16, 57-70. [CrossRef]

65. Ziek, P. Making sense of CSR communication. Corp. Soc. Responsib. Environ. Manag. 2009, 16, 137-145. [CrossRef]

66. Zhu, Q.; Liu, J.; Lai, K.H. Corporate social responsibility practices and performance improvement among Chinese national state-owned enterprises. Int. J. Prod. Econ. 2016, 171, 417-426. [CrossRef]

67. Ali, W.; Frynas, J.G. The Role of Normative CSR-Promoting Institutions in Stimulating CSR Disclosures in Developing Countries. Corp. Soc. Responsib. Environ. Manag. 2018, 25, 373-390. [CrossRef]

68. Dobers, P.; Halme, M. Corporate social responsibility and developing countries. Corp. Soc. Responsib. Environ. Manag. 2009, 16, 237-249. [CrossRef]

69. Hodkinson, P.; Hodkinson, H. The strengths and limitations of case study research. In Proceedings of the Learning and Skills Development Agency Conference at Cambridge, Cambridge, UK, 5-7 December 2001. 